\title{
PENGARUH PRODUK DOMESTIK BRUTO (PDB) DAN INDEKS PEMBANGUNAN MANUSIA (IPM) TERHADAP ANGKA KEMISKINAN DI INDONESIA
}

\author{
Oleh: \\ Muhammad Sri Wahyudi Suliswanto \\ Mahasiswa Magister Ilmu Ekonomi Universitas Brawijaya Malang \\ E-mail/No. Hp: al.ayudie@gmail.com/085697769266
}

\begin{abstract}
Poverty is classic issue faced by most developing countries and is one of economic indicators to view public welfare level in any region. The research aimed to analyze effect of Gross Domestic Product (GDP), and human development index on poverty in Indonesia. Analysis used quantitative with Random Effect Model (REM) method in Panel Data with time series year 2006 to 2008. Anaysis result concluded that all independent variable simultaneously had significant effect on poverty variable in Indonesia and partially Gross Domestic Product (GDP) variable had significant negative influence on poverty with $\alpha 20 \%$, and Human Development Index (HDI) variable had significant negative influence on poverty with $\alpha 5 \%$.
\end{abstract}

Keywords: gross domestic product, human development index, and poverty

\section{PENDAHULUAN}

Produk Domestik Bruto (PDB) Indonesia nampak selalu memberikan prediksi optimistik yang meningkat dari tahun ke tahun. Berdasarkan laporan Badan Pusat Statistik (BPS) secara kumulatif PDB tumbuh 5,9\% per tahun 2010, lebih tinggi bila dibandingkan dengan capaian tahun 2009 pada periode yang sama, yaitu hanya sebesar 5,8\% saja. Cadangan devisa mencapai 94,7 milyar dollar AS dan nilai ekspor mencapai 150 milyar dollar AS. Angka pertumbuhan tersebut sepintas menunjukkan bahwa kinerja ekonomi Indonesia semakin baik. Pihak asing semacam World Economic Forum (WEP) menggambarkan Perekonomian Indonesia mulai digerakkan oleh Efficiency Driven Economy dari semula Factor Driven Economy. Bahkan The Economist menyebutnya sebagai calon kekuatan ekonomi baru dunia (world leading economies).
Namun, apabila dicermati ada indikasi bahwa pertumbuhan ekonomi tersebut adalah petumbuhan yang semu (bubble economics). Hal ini ditandai dengan masih tingginya angka kemiskinan di Indonesia meski pertumbuhan PDB dikatakan bagus. Kemiskinan sudah sejak lama menjadi masalah bangsa Indonesia, dan hingga sekarang masih belum menunjukkan tanda-tanda menghilang. Angka statistik terus saja memberikan informasi masih banyaknya jumlah penduduk miskin, berdasarkan data BPS Jumlah penduduk miskin di Indonesia pada Maret 2010 sebesar 31,02 juta orang (13,33\%).

Kemiskinan merupakan salah satu masalah yang selalu dihadapi oleh manusia. Masalah kemiskinan itu sama tuanya dengan usia kemanusiaan itu sendiri dan implikasi permasalahannya dapat melibatkan keseluruhan aspek kehidupan manusia, walaupun seringkali tidak disadari kehadirannya sebagai 
masalah untuk oleh manusia yang bersangkutan. Bagi mereka yang tergolong miskin, kemiskinan merupakan sesuatu yang nyata ada dalam kehidupan mereka sehari-hari, karena mereka itu merasakan dan menjalani sendiri bagaimana mereka hidup dalam kemiskinan. Walaupun demikian belum tentu mereka itu sadar akan kemiskinan yang mereka jalani. Kesadaran akan kemiskinan yang mereka miliki itu, baru terasa pada waktu mereka membandingkan kehidupan yang mereka jalani dengan kehidupan orang lain yang tergolong mempunyai tingkat kehidupan sosial yang lebih tinggi.

Secara singkat, kemiskinan dapat didefinisikan sebagai suatu standar tingkat hidup yang rendah, yaitu adanya suatu tingkat kekurangan materi pada sejumlah atau segolongan orang dibandingkan dengan standar kehidupan yang umum berlaku dalam masyarakat yang bersangkutan. Standar kehidupan yang rendah ini secara langsung tampak pengaruhnya terhadap tingkat keadaan kesehatan, kehidupan moral, dan rasa harga diri dari mereka yang tergolong sebagai orang miskin.

Berawal dari kemiskinan, maka bermunculan berbagai masalah sosial lainnya. Merebaknya gepeng di jalanan maupun yang berkeliaran di kampungkampung salah satu indikatornya. Begitu pula PSK dan akan anak jalanan yang terkena razia, bisa dipastikan $90 \%$ beralasan karena faktor ekonomi. Belum lagi anak putus sekolah yang selalu meningkat jumlahnya dari tahun ke tahun. Lansia terlantar, anak terlantar, penyandang cacat terlantar, semakin melengkapi data penyandang masalah sosial yang berpangkal pada kemiskinan. Seperti halnya anak-anak yang masih dibawa umur sudah menjadi pengemis.

Pengentasan kemiskinan telah menjadi tujuan pembangunan yang fundamental sehingga menjadi sebuah alat ukur untuk menilai efektivitas berbagai jenis program pembangunan. Pertumbuhan ekonomi dapat menjadi instrumen yang sangat berpengaruh dalam penurunan kemiskinan pendapatan (income poverty).

Pemerintah Indonesia menyadari bahwa pembangunan nasional adalah salah satu upaya untuk menjadi tujuan masyarakat adil dan makmur. Sejalan dengan tujuan tersebut, berbagai kegiatan pembangunan telah diarahkan kepada pembangunan daerah khususnya daerah yang relatif mempunyai kemiskinan yang terus naik dari tahun ke tahun. Pembangunan daerah dilakukan secara terpadu dan berkesinambungan sesuai prioritas dan kebutuhan masingmasing daerah dengan akar dan sasaran pembangunan nasional yang telah ditetapkan melalui pembangunan jangka panjang dan jangka pendek. Oleh karena itu, salah satu indikator utama keberhasilan pembangunan nasional adalah laju penurunan jumlah penduduk miskin. Efektivitas dalam menurunkan jumlah penduduk miskin merupakan pertumbuhan utama dalam memilih strategi atau instrumen pembangunan. Hal ini berarti salah satu kriteria utama pemilihan sektor titik berat atau sektor andalan pembangunan nasional adalah efektivitas dalam penurunan jumlah penduduk miskin (Pantjar Simatupang dan Saktyanu K, 2003).

Oleh karena itu, pemerintah Indonesia dalam menyikapi jumlah kemiskinan tersebut, Pemerintah perlu melakukan empat langkah untuk mengurangi tingkat kemiskinan. Keempat langkah tersebut adalah peningkatan laju pertumbuhan ekonomi, penciptaan lapangan kerja, pemusatan kebijakan sosial ekonomi, dan penyesuaian kebijakan pengurangan kemiskinan sesuai dengan kondisi 
daerah (http://www.gatra.com, 17 Oktober 2003).

Teori pertumbuhan baru menekankan pentingnya peranan pemerintah terutama dalam meningkatkan pembangunan modal manusia (human capital), pningkatan kualitas sumberdaya manusia dapat diperlihatkan oleh meningkatnya pengetahuan dan keterampilan seseorang. Peningkatan pengetahuan dan keahlian akan mampu mendorong peningkatan produktivitas kerja seseorang sehingga akan mampu membantu dalam mengurangi angka kemiskinan. Berdasarkan uraian tersebut, maka peneliti akan menganalisis seberapa besar pengaruh produk domestik bruto (PDB), Indeks Pembangunan Manusia (IPM) terhadap Kemiskinan di Indonesia.

\section{TINJAUAN PUSTAKA}

Secara umum, kemiskinan adalah ketidakmampuan seseorang untuk memenuhi kebutuhan dasar standar atas setiap aspek kehidupan. Menurut Sumitro Djojohadikusumo (1995) pola kemiskinan ada empat yaitu, Pertama adalah persistent poverty, yaitu kemiskinan yang telah kronis atau turun temurun. Pola kedua adalah cyclical poverty, yaitu kemiskinan yang mengikuti pola siklus ekonomi secara keseluruhan. Pola ketiga adalah seasonal poverty, yaitu kemiskinan musiman seperti dijumpai pada kasus nelayan dan petani tanaman pangan. Pola keempat adalah accidental poverty, yaitu kemiskinan karena terjadinya bencana alam atau dampak dari suatu kebijakan tertentu yang menyebabkan menurunnya tingkat kesejahteraan suatu masyarakat.

Sedangkan menurut BPS (Badan Pusat Statistik), tingkat kemiskinan didasarkan pada jumlah rupiah konsumsi berupa makanan yaitu 2100 kalori per orang per hari (dari 52 jenis komoditi yang dianggap mewakili pola konsumsi penduduk yang berada dilapisan bawah), dan konsumsi nonmakanan (dari 45 jenis komoditi makanan sesuai kesepakatan nasional dan tidak dibedakan antara wilayah pedesaan dan perkotaan). Patokan kecukupan 2100 kalori ini berlaku untuk semua umur, jenis kelamin, dan perkiraan tingkat kegiatan fisik, berat badan, serta perkiraan status fisiologis penduduk, ukuran ini sering disebut dengan garis kemiskinan. Penduduk yang memiliki pendapatan dibawah garis kemiskinan dikatakan dalam kondisi miskin.

Adapun pertumbuhan ekonomi adalah kenaikan kapasitas dalam jangka panjang dari negara yang bersangkutan untuk menyediakan berbagai barang ekonomi kepada penduduknya yang ditentukan oleh adanya kemajuan atau penyesuaian teknologi, institusional (kelembagaan), dan ideologis terhadap berbagai tuntutan keadaan yang ada (Kuznetz dalam Todaro, 2004).

Pertumbuhan ekonomi berkaitan dengan kenaikan produksi suatu negara atau kenaikan pendapatan per kapita suatu negara. Oleh karena itu pertumbuhan ekonomi erat kaitannya dengan produk domestik bruto (PDB) atau produk domestik regional bruto (PDRB) jika dalam lingkup daerah.

Beberapa hasil kajian dan penelitian telah diperoleh bahwa pertumbuhan ekonomi, IPM, dan kemiskinan memiliki keterkaitan yang erat. Asian Development Bank (2008) menyatakan bahwa pertumbuhan ekonomi yang dinamis telah banyak mengurangi kemiskinan. Jumlah penduduk yang berjuang untuk hidup dengan $\$ 1$ atau kurang per hari telah turun dari 900 juta tahun 1990 menjadi 600 juta sekarang. Ini dapat diartikan sebagai peningkatan pendidikan, kesehatan yang lebih baik, usia yang lebih panjang, dan kesempatan yang lebih besar.

Siregar dan Wahyuniarti (2008) meneliti mengenai dampak pertumbuhan ekonomi terhadap penurunan jumlah penduduk miskin diperoleh hasil bahwa 
pertumbuhan ekonomi berpengaruh signifikan terhadap penurunan jumlah penduduk miskin walaupun dengan magnitude yang relatif kecil, seperti inflasi, populasi penduduk, share sektor pertanian, dan sektor industri.

Selain itu Sjafi'i dan Hidayati (2009) menyatakan bahwa Tersedianya SDM yang berkualitas ini merupakan syarat penting berlangsungnya pembangunan ekonomi secara berkesinambungan. Pengalaman pembangunan ekonomi negara macan Asia (Korea Selatan, Singapura, Taiwan, Hongkong) membuktikan investasi modal manusia (lewatproses pendidikan) lebih "mujarab" dibanding investasi fisik (gedung, infrastruktur lainnya).

Sitepu dan Sinaga (2003) mengkaji mengenai dampak investasi sumber daya manusia terhadap kemiskinan diperoleh hasil bahwa Investasi sumberdaya manusia untuk pendidikan dapat menurunkan poverty incidence, poverty depth dan poverty severity kecuali untuk rumahtangga bukan pertanian golongan atas di desa, bukan angkatan kerja di kota dan bukan pertanian golongan atas di kota, sedangkan investasi kesehatan hanya di rumahtangga bukan pertanian golongan atas di kota yang mengalami peningkatan sementara rumahtangga lainnya mengalami penurunan indeks kemiskinan.

\section{METODE PENELITIAN}

Penelitian ini mengenai pengaruh produk domestik bruto (PDB), indeks pembangunan manusia (IPM) terhadap kemiskinan di Indonesia, peneliti melakukan studi empiris dengan obyek penelitian seluruh propinsi di Indonesia pada tahun 2006 - 2008, untuk variabel PDB akan digunakan nilai PDRB masing-masing propinsi. Adapun data yang digunakan dalam penelitian ini merupakan data sekunder yang diperoleh dari Badan Pusat Statistik (BPS). Variabel-variabel yang diteliti dalam penelitian ini yaitu variabel PDRB, IPM, dan Prosentase kemiskinan di masingmasing propinsi yang ada di Indonesia.

Teknik analisis dalam penelitian ini yaitu analisis regresi data panel, adapun model regresinya dalam bentuk log dapat ditulis sebagai berikut:

$$
\ln \mathrm{Y}_{\mathrm{it}}=\beta_{0}+\beta_{1} \ln \mathrm{X}_{1 \mathrm{it}}+\beta_{2} \ln \mathrm{X}_{2 \mathrm{it}}+\mathrm{e}_{\mathrm{it}}
$$

dimana: $\mathrm{Y}=$ Kemiskinan; $\mathrm{X}_{1}=$ PDRB; $\mathrm{X}_{2}=$ IPM; $\mathrm{i}=$ daerah; dan $\mathrm{t}=$ waktu.

Ada dua pendekatan mendasar yang digunakan dalam menganalisis data panel. Pertama, pendekatan Fixed Effect yaitu teknik mengestimasi data panel dengan menggunakan variabel dummy untuk menangkap adanya perbedaan intersep. Kedua, pendekatan Random Effect yaitu estimasi data panel dimana residual mungkin saling berhubungan antar waktu dan antar individu. Sebelum model diestimasi dengan model yang tepat, terlebih dahulu dilakukan uji spesifikasi apakah Fixed Effect atau Random Effect atau keduanya memberikan hasil yang sama. Pilihan antara Fixed Effect dan Random Effect ditentukan dengan menggunakan Hausman's Test.

Adapun ketentuan Hausman's Test yaitu apabila nilai statistik Hausman lebih besar dari nilai kritisnya maka model yang lebih tepat adalah model Fixed Effect sedangkan sebaliknya bila nilai statistik Hausman lebih kecil dari nilai kritisnya maka model yang tepat adalah Random Effect.

Uji signifikansi dalam penelitian ini dilakukan secara parsial dan simultan. Secara parsial dilakukan uji t test, sedangkan secara simultan dilakukan uji $\mathrm{F}$ test.

$\mathrm{Uji} \mathrm{t}$ test digunakan untuk mengetahui apakah masing-masing variabel bebas secara parsial mempunyai pengaruh yang signifikan terhadap variabel terikat. Dapat juga dikatakan 
jika $\mathrm{t}$ hitung $>\mathrm{t}$ tabel atau $-\mathrm{t}$ hitung $<-\mathrm{t}$ tabel maka hasilnya signifikan dan berarti $\mathrm{H}_{0}$ ditolak dan $\mathrm{H}_{1}$ diterima. Sedangkan jika $\mathrm{t}$ hitung $<\mathrm{t}$ tabel atau $-\mathrm{t}$ hitung > $-\mathrm{t}$ tabel maka hasilnya tidak signifikan dan berarti $\mathrm{H}_{0}$ diterima dan $\mathrm{H}_{1}$.

Pengujian $\mathrm{F}$ atau pengujian model digunakan untuk mengetahui apakah hasil dari analisis signifikan atau tidak, dengan kata lain model yang diduga tepat/sesuai atau tidak. Jika hasilnya signifikan, maka $\mathrm{H}_{0}$ ditolak dan $\mathrm{H}_{1}$ diterima. Sedangkan jika hasilnya tidak signifikan, maka $\mathrm{H}_{0}$ diterima dan $\mathrm{H}_{1}$ ditolak. Hal ini dapat juga dikatakan sebagai berikut: $\mathrm{H}_{0}$ ditolak jika $\mathrm{F}$ hitung
$>\mathrm{F}$ tabel; $\mathrm{H}_{0}$ diterima jika $\mathrm{F}$ hitung $<\mathrm{F}$ tabel.

\section{PEMBAHASAN}

Kendati pertumbuhan ekonomi Indonesia relatif tinggi yaitu bekisar 5,9\% dan bahkan pada tahun 2011 pemerintah memprediksikan mencapai 7\%, namun angka kemiskinan di Indonesia masih tinggi. Adapun perkembangan pertumbuhan ekonomi pada tahun 2004 - 2010 dapat dilihat pada gambar 1.

Sedangkan perkembangan tingkat kemiskinan pada tahun 2004-2010 dapat dilihat pada tabel 1 .

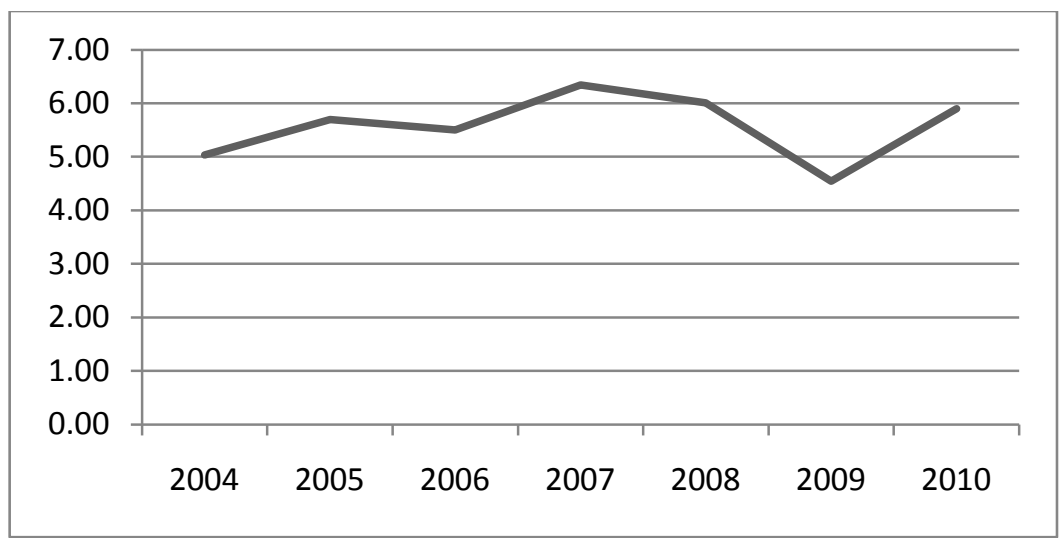

Gambar 1. Pertumbuhan Ekonomi di Indonesia Tahun 2004 - 2010

Sumber: World bank dan BPS (diolah)

Tabel 1. Jumlah dan Persentase Penduduk Miskin di Indonesia Menurut Daerah, 2004-2010

\begin{tabular}{lcccccc}
\hline \multirow{2}{*}{ Tahun } & \multicolumn{2}{c}{ Jumlah Penduduk Miskin (Juta) } & \multicolumn{3}{c}{ Persentase Penduduk Miskin } \\
& Kota & Desa & Kota+Desa & Kota & Desa & Kota+Desa \\
& & & & & & \\
\hline 2004 & 11,40 & 24,80 & 36,10 & 12,13 & 20,11 & 16,66 \\
2005 & 12,40 & 22,70 & 35,10 & 11,68 & 19,98 & 15,97 \\
2006 & 14,49 & 24,81 & 39,30 & 13,47 & 21,81 & 17,75 \\
2007 & 13,56 & 23,61 & 37,17 & 12,52 & 20,37 & 16,58 \\
2008 & 12,77 & 22,19 & 34,96 & 11,65 & 18,93 & 15,42 \\
2009 & 11,91 & 20,62 & 32,53 & 10,72 & 17,35 & 14,15 \\
2010 & 11,10 & 19,93 & 31,02 & 9,87 & 16,56 & 13,33 \\
\hline
\end{tabular}

Sumber: BPS 
Berdasarkan data diatas, jumlah penduduk miskin menujukkan angka yang cenderung menurun, Jumlah penduduk miskin di Indonesia pada Maret 2010 turun menjadi 31,02 juta orang (13,33 persen) jika dibandingkan dengan penduduk miskin pada Maret 2009 yang berjumlah 32,53 juta $(14,15$ persen).

Jumlah penduduk miskin di daerah perkotaan turun lebih besar daripada daerah perdesaan. Selama periode Maret 2009-Maret 2010, penduduk miskin di daerah perkotaan berkurang 0,81 juta orang, sementara di daerah perdesaan berkurang 0,69 juta orang. Persentase penduduk miskin antara daerah perkotaan dan perdesaan tidak banyak berubah dari Maret 2009 ke Maret 2010. Pada Maret 2009, sebagian besar $(63,38$ persen) penduduk miskin berada di daerah perdesaan begitu juga pada Maret 2010 , yaitu sebesar 64,23 persen.

Untuk menekan angka kemiskinan, seringkali pemerintah mengambil langkah untuk meningkatkan pertumbuhan ekonomi dengan mengharapkan terjadinya efek menetes ke bawah (trickle down effect), selain itu untuk mengatasi kemiskinan juga perlu ditingkatkan indeks pembangunan manusia (IPM). Peningkatan pertumbuhan ekonomi erat kaitannya dengan peningkatan PDB atau PDRB jika dalam lingkup daerah.

Oleh karena itu untuk mengetahui besarnya pengaruh PDRB, IPM terhadap kemiskinan dilakukan analisis data panel dengan pendekatan Random effect. Model ini dipilih dikarenakan berdasarkan Hausman's Test nilai statistik Hausman (2.539) lebih kecil dari nilai kritis chi square $(9,2103)$, maka model yang tepat untuk analisis adalah model Random Effect daripada model Fixed Effect. Adapun model hasil analisis masing-masing propinsi dapat diinterpretasikan pada tabel 2.

Berdasarkan tabel 2, dapat diketahui nilai constanta masing-masing propinsi. Nilai constanta tertinggi adalah Irian Jaya Barat yaitu sebesar 23,016 berarti kemiskinan (Ln Y) di Irian Jaya Barat sebesar 23,016\% pada saat PDRB $\left(\operatorname{Ln} X_{1}\right)$, dan IPM $\left(\operatorname{Ln~} X_{2}\right)$ sama dengan atau dianggap nol (konstan). Sementara constanta terendah adalah Kalimantan Selatan yaitu sebesar 21,445 yang berarti kemiskinan (Ln Y) di Kalimantan Selatan sebesar $21,445 \%$ pada saat PDRB $\left(\operatorname{Ln} X_{1}\right)$, dan IPM $\left(\operatorname{Ln} X_{2}\right)$ sama dengan atau dianggap nol (konstan). Hal ini mengindikasikan ketika PDRB dan IPM dalam kondisi konstan, maka angka kemiskinan tertinggi akan terjadi di Irian Jaya Barat.

Adapun nilai $\beta_{1}$ merupakan koefisien regresi variabel PDRB $\left(\operatorname{Ln} \mathrm{X}_{1}\right)$ untuk semua propinsi sebesar -0,011 berarti ada pengaruh negatif antara PDRB terhadap kemiskinan sebesar 0,011\%. Apabila PDRB ( $\operatorname{Ln} \mathrm{X}_{1}$ ) naik sebesar $1 \%$ maka Kemiskinan (Ln Y) akan mengalami penurunan sebesar 0,011\%. Sebaliknya apabila PDRB (Ln $\mathrm{X}_{1}$ ) turun sebesar $1 \%$ maka Kemiskinan (Ln Y) akan naik sebesar 0,011\%.

Sedangkan nilai $\beta_{2}$ merupakan koefisien regresi variabel IPM $\left(\operatorname{Ln} \mathrm{X}_{2}\right)$ untuk semua propinsi sebesar $-4,582$ berarti ada pengaruh negatif antara IPM terhadap kemiskinan sebesar 4,582\%. Apabila IPM ( $\left.\operatorname{Ln~} \mathrm{X}_{2}\right)$ naik sebesar $1 \%$ maka Kemiskinan (Ln Y) akan mengalami penurunan sebesar 4,582\%. Sebaliknya apabila IPM $\left(\operatorname{Ln} \mathrm{X}_{2}\right)$ turun sebesar 1\% maka Kemiskinan (Ln Y) akan naik sebesar 4,582\%. Bagaimana variabel-variabel berpengaruh terhadap kemiskinan di propinsi yang ada di Indonesia dapat terlihat pada tabel 3. 
Tabel 2. Model Pengaruh PDRB dan IPM terhadap Kemiskinan di masing-masing Propinsi

\begin{tabular}{ll}
\hline \multicolumn{1}{c}{ Propinsi } & Model \\
\hline Naggroe Aceh Darussalam & $22,863-0,011 \ln \mathrm{X}_{1}-4,582 \ln \mathrm{X}_{2}$ \\
Sumatera Utara & $22,403-0,011 \ln \mathrm{X}_{1}-4,582 \ln \mathrm{X}_{2}$ \\
Sumatera Barat & $22,188-0,011 \ln \mathrm{X}_{1}-4,582 \ln \mathrm{X}_{2}$ \\
Riau & $22,293-0,011 \ln \mathrm{X}_{1}-4,582 \ln \mathrm{X}_{2}$ \\
Jambi & $22,023-0,011 \ln \mathrm{X}_{1}-4,582 \ln \mathrm{X}_{2}$ \\
Sumatera Selatan & $22,653-0,011 \ln \mathrm{X}_{1}-4,582 \ln \mathrm{X}_{2}$ \\
Bengkulu & $22,758-0,011 \ln \mathrm{X}_{1}-4,582 \ln \mathrm{X}_{2}$ \\
Lampung & $22,669-0,011 \ln \mathrm{X}_{1}-4,582 \ln \mathrm{X}_{2}$ \\
Bangka Belitung & $21,955-0,011 \ln \mathrm{X}_{1}-4,582 \ln \mathrm{X}_{2}$ \\
Kepulauan Riau & $22,169-0,011 \ln \mathrm{X}_{1}-4,582 \ln \mathrm{X}_{2}$ \\
DKI Jakarta & $21,542-0,011 \ln \mathrm{X}_{1}-4,582 \ln \mathrm{X}_{2}$ \\
Jawa Barat & $22,279-0,011 \ln \mathrm{X}_{1}-4,582 \ln \mathrm{X}_{2}$ \\
Jawa Tengah & $22,694-0,011 \ln \mathrm{X}_{1}-4,582 \ln \mathrm{X}_{2}$ \\
DI Yogyakarta & $22,788-0,011 \ln \mathrm{X}_{1}-4,582 \ln \mathrm{X}_{2}$ \\
Jawa Timur & $22,589-0,011 \ln \mathrm{X}_{1}-4,582 \ln \mathrm{X}_{2}$ \\
Banten & $21,740-0,011 \ln \mathrm{X}_{1}-4,582 \ln \mathrm{X}_{2}$ \\
Bali & $21,520-0,011 \ln \mathrm{X}_{1}-4,582 \ln \mathrm{X}_{2}$ \\
Nusa Tenggara Barat & $22,494-0,011 \ln \mathrm{X}_{1}-4,582 \ln \mathrm{X}_{2}$ \\
Nusa Tenggara Timur & $22,637-0,011 \ln \mathrm{X}_{1}-4,582 \ln \mathrm{X}_{2}$ \\
Kalimantan Barat & $21,984-0,011 \ln \mathrm{X}_{1}-4,582 \ln \mathrm{X}_{2}$ \\
Kalimantan Tengah & $22,098-0,011 \ln \mathrm{X}_{1}-4,582 \ln \mathrm{X}_{2}$ \\
Kalimantan Selatan & $21,445-0,011 \ln \mathrm{X}_{1}-4,582 \ln \mathrm{X}_{2}$ \\
Kalimantan Timur & $22,175-0,011 \ln \mathrm{X}_{1}-4,582 \ln \mathrm{X}_{2}$ \\
Sulawesi Utara & $22,294-0,011 \ln \mathrm{X}_{1}-4,582 \ln \mathrm{X}_{2}$ \\
Sulawesi Tengah & $22,627-0,011 \ln \mathrm{X}_{1}-4,582 \ln \mathrm{X}_{2}$ \\
Sulawesi Selatan & $22,157-0,011 \ln \mathrm{X}_{1}-4,582 \ln \mathrm{X}_{2}$ \\
Sulawesi Tenggara & $22,519-0,011 \ln \mathrm{X}_{1}-4,582 \ln \mathrm{X}_{2}$ \\
Gorontalo & $22,794-0,011 \ln \mathrm{X}_{1}-4,582 \ln \mathrm{X}_{2}$ \\
Sulawesi Barat & $22,363-0,011 \ln \mathrm{X}_{1}-4,582 \ln \mathrm{X}_{2}$ \\
Maluku & $22,987-0,011 \ln \mathrm{X}_{1}-4,582 \ln \mathrm{X}_{2}$ \\
Maluku Utara & $21,894-0,011 \ln \mathrm{X}_{1}-4,582 \ln \mathrm{X}_{2}$ \\
Irian Jaya Barat & $22,807-0,011 \ln \mathrm{X}_{1}-4,582 \ln \mathrm{X}_{2}$ \\
Papua & \\
\hline
\end{tabular}

Tabel 3. Pengaruh Masing-Masing Variabel terhadap GDP di ASEAN-5

\begin{tabular}{lcc}
\hline \multicolumn{1}{c}{ Variabel } & Koefisien & Probabilitas \\
\hline Produk Domestik Regional Bruto & $-0,011 * *$ & 0.1320 \\
Indeks Pembangunan Manusia & $-4,582 *$ & 0,0000 \\
\hline
\end{tabular}

\section{Keterangan:}

$$
\begin{array}{ll}
* & =\text { signifikan pada } \alpha 5 \% \\
* * & =\text { signifikan pada } \alpha 20 \% \\
\mathrm{R}^{2} & =0,9928 \text { atau } 99,28 \% \\
\text { F-stat } & =136,47
\end{array}
$$


Dari hasil regresi data panel tersebut dapat disimpulkan bahwa secara parsial PDRB $\left(\mathrm{X}_{1}\right)$ dan IPM $\left(\mathrm{X}_{2}\right)$ berpengaruh negatif dan signifikan terhadap variabel terkait (Kemiskinan), hanya saja berbeda tingkat signifikansinya yaitu untuk PDRB signifikan pada $\alpha 20 \%$ dan untuk IPM signifikan pada $\alpha 5 \%$. Sedangkan secara simultan, nilai $\mathrm{F}$ hitung sebesar 136,47 Sedangkan F tabel $(\alpha=0.05$; db regresi $=2: \mathrm{db}$ residual $=60)$ adalah sebesar 4,00. Karena F hitung > F tabel yaitu $136,47>4,00$ maka analisis regresi adalah signifikan. Sehingga secara simultan pengaruh PDRB $\left(\mathrm{X}_{1}\right)$ dan IPM $\left(\mathrm{X}_{2}\right)$ terhadap Kemiskinan (Y) adalah besar.

Langkah berikutnya yaitu melihat nilai koefisien determinasi yang digunakan untuk mengetahui kontribusi variabel bebas terhadap variabel terikat. Koefisien determinasi $\left(\mathrm{R}^{2}\right)$ maupun koefisien determinasi yang disesuaikan menunjukkan variabel penjelas dalam menjelaskan variasi variabel terikat. Jika nilai $\mathrm{R}^{2}$ semakin mendekati 1 maka dapat dinyatakan model semakin baik dengan asumsi tidak terjadi regresi lancung.

Adapun nilai koefisien determinasi $\mathrm{R}^{2}$ sebesar 0,9928 Artinya bahwa 99,28\% variabel kemiskinan akan dijelaskan oleh variabel bebasnya, yaitu PDRB dan IPM. Sedangkan sisanya sebesar $0,72 \%$ variabel kemiskinan akan dijelaskan oleh variabel-variabel yang lain yang tidak dibahas dalam penelitian ini. Model ini juga telah lolos uji autokorelasi dan multikolinieritas.

Untuk mengetahui variabel yang mempunyai pengaruh paling dominan terhadap besarnya kemiskinan selama periode penelitian dapat dilihat dari nilai probabilitas. Variabel bebas memiliki nilai probabilitas yang terendah menunjukkan bahwa variabel tersebut merupakan variabel yang memiliki pengaruh paling dominan terhadap variabel terikat.

Berdasarkan hasil perhitungan dan dapat dilihat pada tabel 3, maka dengan membandingkan nilai probabilitas dari masing-masing variabel dapat diambil kesimpulan bahwa variabel yang mempunyai pengaruh paling dominan terhadap besarnya kemiskinan adalah IPM.

Pada penelitian ini variabel PDRB memiliki signifikansi pengaruh terhadap kemiskinan hanya pada $\alpha 20 \%$, hal ini sesuai temuan dari world bank (2006) bahwa pertumbuhan ekonomi belum dapat secara signifikan mengurangi kemiskinan dikarenakan pola dari pertumbuhan ekonomi di Indonesia yaitu terjadinya ketimpangan. Sejak tahun 1998, pertumbuhan bukan saja berjalan dengan tingkat yang lebih rendah, tetapi juga menjadi semakin kurang merata. Sehingga Jumlah penduduk miskin tidak akan dapat dikurangi secara signifikan tanpa adanya pertumbuhan ekonomi yang bermanfaat bagi orang miskin. Menurut world bank (2006) pada periode setelah krisis, berkurangnya penduduk miskin lebih banyak disebabkan karena membaiknya stabilitas ekonomi dan turunnya harga bahan makanan.

\section{PENUTUP}

Perekonomian indonesia mengalami pertumbuhan ekonomi yang relatif bagus akhir-akhir ini. Namun hal ini belum memberikan pengaruh yang signifikan terhadap pengurangan angka kemiskinan.

Hasil analisis diperoleh nilai PDRB di masing-masing propinsi belum terlalu besar dalam mengurangi angka kemiskinan. Namun lebih dominan pengurangan angka kemiskinan dari variabel IPM. Hal ini mengindikasikan pertumbuhan ekonomi yang terjadi belum pro orang miskin atau dalam kata 
lain belum banyak memberikan manfaat bagi orang miskin.

Temuan di atas menunjukkan bahwa permasalahan kemiskinan tidak cukup hanya dipecahkan melalui meningkatkan pertumbuhan ekonomi semata dengan mengharapkan terjadinya efek menetes ke bawah (trickle down effect). Peningkatan kualitas SDM akan mampu memberikan pengaruh yang besar terhadap pengurangan angka kemiskinan yang terjadi.

Metode pertumbuhan ekonomi belum mampu sebagai problem solving disebabkan kesalahan konsep ini dalam memandang kemiskinan yang harus dipecahkan, yakni kemiskinan yang menimpa negara bukan kemiskinan yang menimpa individu. Juga konsep ini menitikberatkan perhatiannya pada aspek produksi barang dan jasa bukan pada aspek pemenuhan kebutuhan masayarakat.

Oleh karena itu, kemiskinan yang harus dipecahkan adalah kemiskinan yang menimpa individu sehingga yang harus dilakukan adalah menjamin pemenuhan kebutuhan pokoknya serta mendorong mereka untuk memenuhi kebutuhan sekunder dan tersiernya, dan jalan untuk mencapainya adalah dengan menciptakan distribusi ekonomi yang adil (pemerataan) di tengah-tengah masyarakat atau dengan kata lain merubah pola pertumbuhan ekonomi yang salama ini terjadi ke arah pertumbuhan ekonomi yang lebih berpihak kepada orang miskin.

\section{DAFTAR PUSTAKA}

Ahmad Sjafi'i dan Nur Aini Hidayati. 2009. Genjot Anggaran Pendidikan-Redam Kemiskinan, dalam Gemari Edisi 101/Tahun X/Juni 2009: 68-69
Arsyad, Lincolin. 1999. Ekonomi Pembangunan (Edisi Keempat). Yogyakarta: STIE-YKPN.

Asian Development Bank. 2008. Melawan Kemiskinan di Asia Pasifik.

Badan Pusat Statistik. 2010. Berita Resmi Statistik. No. 45/07/Th. XIII, 1 Juli 2010

Departemen Komunikasi dan Informatika. 2008. Mengurai Benang Kusut Masalah Kemiskinan di Indonesia. Jurnal Dialog Kebijakan Publik. Edisi 3 / November/Tahun II/2008.

Hermanto Siregar dan Dwi Wahyuniarti, 2008, Dampak Pertumbuhan Ekonomi Terhadap Penurunan Jumlah Penduduk Miskin. Online at

http://pse.litbang.deptan.go.id/ind/ pdffiles/PROS_2008_MAK3.pdf. Diakses tanggal 15 Januari 2011.

Mudrajad Kuncoro. 2003. Ekonomi Pembangunan: Teori, Masalah dan Kebijakan. (2nd ed.). Yogyakarta: UPP AMP YKPN.

Nssah, B. Essama dan Lambert, Peter J. 2006. Measuring the Pro-Poorness of Income Growth within an Elasticity Framework. World Bank Policy Research Working Paper 4035

Pantjar Simatupang dan Saktyanu K. Dermoredjo, 2003, Produksi Domestik Bruto, Harga, dan Kemiskinan, dalam Media Ekonomi dan Keuangan Indonesia, Vol. 51, No. 3, Hal. 191 - 324. 
Rasidin K. Sitepu dan Bonar M. Sinaga. 2004. Dampak Investasi Sumber Daya Manusia terhadap Pertumbuhan Ekonomi dan Kemiskinan Di Indonesia: Pendekatan Model Computable General Equilibrium. Online at http://ejournal.unud.ac.id/?module $=$ detailpenelitian $\& \mathrm{idf}=7 \& \mathrm{idj}=48 \& \mathrm{i}$ $\mathrm{dv}=181 \& \mathrm{idi}=\quad$ 48\&idr $=191$. Diakses tanggal 15 Januari 2011.

Sadono Sukirno. 2006. Ekonomi Pembangunan (Edisi Kedua). Jakarta: Kencana.

Sudarno Sumarto, dkk. 2004. Tata Kelola Pemerintah dan Penanggulangan Kemiskinan: Bukti-bukti Awal Desentralisasi di Indonesia. Lembaga Penelitian SMERU

Sumitro Djojohadikusumo. 1995. Perkembangan Pemikiran Ekonomi Dasar Teori Pertumbuhan dan Ekonomi Pembangunan. Jakarta: LP3ES.

Todaro, Michael P. dan Stephen C. Smith. 2004. Pembangunan Ekonomi di Dunia Ketiga, Edisi kedelapan. Erlangga: Jakarta.

World Bank. 2006. Making the New Indonesia Work for the Poor.

www.bps.go.id

www.worldbank.org 